\title{
Dead or alive?
}

\section{De invloed van incidentkenmerken en gedragingen van actoren op fatale versus niet-fatale uitkomsten van geweld*}

\author{
Soenita Ganpat, Joanne van der Leun \& Paul Nieuwbeerta
}

\begin{abstract}
Sommige ernstige geweldsincidenten eindigen met dodelijke afloop, andere niet. Om te onderzoeken welke factoren bij dit verschil in afloop een rol spelen, bestudeerden we op basis van strafdossiers in hoeverre een aantal geselecteerde incidentkenmerken en gedragingen van actoren bijdroeg aan de escalatie van conflicten. Hiertoe zijn 267 ernstige geweldsincidenten bestudeerd waarbij daders veroordeeld waren voor fataal geweld (moord/doodslag, $N=126$ ) of niet-fataal geweld (poging moord/doodslag, $N=141$ ). De resultaten tonen substantiële verschillen tussen conflicten met een fatale en niet-fatale afloop op het punt van incidentkenmerken en vooral van gedragingen van actoren gedurende het incident. De kans op een fatale afloop blijkt vooral toe te nemen wanneer sprake is van alcoholgebruik door slachtoffers, vuurwapengebruik door daders, bepaalde gedragingen geïnitieerd door het slachtoffer en afwezigheid van omstanders.
\end{abstract}

\section{Introductie}

Sommige ernstige geweldsconflicten eindigen fataal, andere niet. Deze studie maakt deel uit van een groter onderzoek naar de rol van individuele karaktereigenschappen en bepaalde situationele kenmerken bij het fataal versus niet-fataal eindigen van ernstige geweldsincidenten. Dit artikel focust op situationele kenmerken en individuele karaktereigenschappen worden buiten beschouwing gelaten. In dit artikel beogen we inzicht te verschaffen in het waarom van dit cruciale verschil in afloop door de directe context en interacties tijdens een specifieke selectie van geweldsincidenten (namelijk ernstig geweld) te bestuderen. Eerder onderzoek benadrukt het belang van individuele karaktereigenschappen (zoals criminele geneigdheid) en situationele kenmerken (zoals incidentkenmerken en gedragingen van actoren) (o.a. Felson \& Steadman, 1983; Gottfredson \& Hirschi, 1990; Nieuwenhuis \& Ferwerda, 2010; Phillips \& Cooney, 2005; Weaver e.a., 2004). Wat betreft situationele kenmerken komen incidentkenmerken zoals bepaalde tijden, locaties, alcoholgebruik en aanwezigheid van omstanders vaker voor bij fatale dan niet-fatale incidenten. Dit is in lijn met de routineactiviteitentheorie (hierna: RAT) die veronderstelt dat bij bepaalde incidentkenmerken de

* $\quad$ Met dank aan de anonieme reviewers en de redactie voor commentaren op een eerdere versie van dit artikel en aan de onderzoeksassistenten die met doorzettingsvermogen en precisie de dossiers hebben geanalyseerd: Daphne Blokdijk, Laura Haasnoot, Paula Kennis, Floor Oosterwechel, Inge Schepens, Arjen Stroo, Jokelien van Vliet en Jacob de Vrind. 
gelegenheid tot (gewelds)criminaliteit toeneemt (Cohen \& Felson, 1979). Andere onderzoeken benadrukken het belang van menselijke interacties tijdens conflictsituaties, die mogelijkerwijs bijdragen aan de escalatie van geweld (o.a. Beke e.a., 2001; Decker, 1995; Dümig \& Van Dijk, 1975; Felson \& Steadman, 1983; Luckenbill, 1977; Von Hentig, 1948; Wolfgang, 1958).

In vergelijking met studies naar individuele karaktereigenschappen is veel minder onderzoek gedaan naar de rol van situationele kenmerken bij geweldsincidenten (Phillips e.a., 2007). Het beschikbare onderzoek naar situationele kenmerken is doorgaans louter beschrijvend en veelal incompleet vanwege de exclusieve blik op daders (Phillips e.a., 2007). Ook is onbekend in hoeverre incidentkenmerken en gedragingen van actoren verschillen bij fatale versus niet-fatale geweldsincidenten. Deze studie beoogt de voornoemde leemtes te vullen door twee selecte steekproeven van ernstige geweldsincidenten te vergelijken: (1) ernstige geweldsincidenten waarbij sprake is van moord/doodslag (d.w.z. fatale incidenten) en (2) ernstige geweldsincidenten waarbij sprake is van pogingen daartoe (d.w.z. nietfatale geweldsincidenten).

Uniek aan deze studie is dat we voltooide en gepoogde moord-/doodslagzaken hebben samengebracht in een database en expliciet met elkaar vergelijken, waarbij we kijken naar zowel daders en slachtoffers als omstanders. Aangezien het uitvoeren van dit type onderzoek niet zonder problemen is - slachtoffers die gedood zijn, zijn immers niet in staat hun verhaal te vertellen, hetgeen een bias kan veroorzaken - zijn grote inspanningen geleverd om voor beide typen incidenten een zo accuraat mogelijke reconstructie te geven van wat zich ten tijde van het incident heeft plaatsgevonden. Op basis van grondige systematische analyses van omvangrijke strafdossiers focust deze studie op een aantal incidentkenmerken en gedragingen van actoren gedurende het incident die in de literatuur van cruciaal belang worden geacht voor de uitkomst van ernstige geweldsincidenten. Incidentkenmerken verwijzen naar de directe context of setting waarin incidenten zich afspelen, in casu de locatie, de tijd van het incident, alcoholgebruik door het slachtoffer en/of de dader, de aanwezigheid van omstanders en het aantal aanwezige omstanders.

De volgende onderzoeksvragen staan centraal: (1a) in hoeverre zijn er verschillen tussen fatale versus niet-fatale geweldsincidenten in incidentkenmerken, en (1b) ten aanzien van gedragingen van daders, slachtoffers en omstanders ten tijde van het incident; en in hoeverre zijn (2a) incidentkenmerken en (2b) gedragingen van daders, slachtoffers en omstanders gedurende het incident van invloed op de kans dat ernstige geweldsincidenten fataal eindigen? In het navolgende gaan we na wat hierover al bekend is.

\section{Eerder onderzoek}

\section{Incidentkenmerken}

Eerder onderzoek bevestigt het belang van incidentkenmerken. Weaver e.a. (2004) lieten zien dat wanneer geweldsincidenten overdag of in een woning plaatsvinden, de kans op een fatale afloop toeneemt. Veel studies vonden boven- 
dien niet alleen een link tussen alcoholgebruik door daders en (fataal) geweld (zie de reviewstudie van Darke, 2010), maar soms ook tussen middelengebruik van slachtoffers en fatale versus niet-fatale uitkomsten. Zo concluderen Felson en Steadman (1983) dat slachtoffers van fatale incidenten vaker onder invloed waren van alcohol of drugs dan slachtoffers van niet-fataal geweld. Onderzoek is echter niet eenduidig over de vraag of daders van fataal geweld vaker onder invloed zijn van middelengebruik dan daders van niet-fataal geweld (o.a. DiCataldo \& Everett, 2008; Dobash e.a., 2007; Felson \& Steadman, 1983). Hoewel weinig studies verricht zijn naar de aanwezigheid van omstanders bij fatale versus niet-fatale incidenten, blijkt dat de meerderheid van mishandeling en levensdelicten (ongeveer 70 procent) in de aanwezigheid van een omstander plaatsvond (Felson \& Steadman, 1983; Luckenbill, 1977; Planty, 2002), en dat omstanders de ernst van incidenten kunnen beïnvloeden. Onduidelijk is echter of de aanwezigheid van omstanders een escalerende of de-escalerende uitwerking heeft (o.a. Apel e.a., 2011; Decker, 1995; Luckenbill, 1977; Phillips \& Cooney, 2005). Hoewel RAT tot slot suggereert dat een groter aantal aanwezige omstanders de pool van adequate toezichthouders verhoogt, suggereert eerder onderzoek naar niet-fataal geweld echter het tegenovergestelde. Zo kan onder andere het zogeheten 'bystander effect' optreden (Latane \& Darley, 1968).

\section{Gedraging van actoren}

Eerder onderzoek naar fataal en niet-fataal geweld biedt steun voor de assumptie dat gedragingen van actoren een centrale rol kunnen spelen bij de uitkomst van incidenten. Zo liet Wolfgang (1958) zien dat slachtoffers van fatale incidenten aan hun eigen dood kunnen bijdragen door als eerste een vuurwapen of mes te tonen of fysiek geweld te gebruiken, wat hij als 'victim precipitation'1 definieerde. Curtis (1974) vond een hoger percentage van 'victim precipitation' bij levensdelicten (22 procent) en zware mishandeling (14 procent) dan bij andere geweldsdelicten, zoals verkrachting en overval. Het schaarse beschikbare onderzoek naar het gedrag van slachtoffers in gewelddadige incidenten vond dat slachtoffers van fataal geweld vaker agressief waren dan slachtoffers van niet-fataal geweld. Zo waren slachtoffers van fataal geweld eerder geneigd om (1) de dader te beledigen, (2) de dader te bedreigen, (3) fysiek geweld te gebruiken, en (4) een wapen (ongeacht het soort) te tonen of te gebruiken dan slachtoffers van niet-fataal geweld (Felson \& Steadman, 1983). Bovendien blijkt dat het type wapen - vooral vuurwapens en messen - van cruciaal belang is voor de kans op een fatale uitkomst, hetgeen in het bijzonder geldt voor daders² (o.a. Felson \& Messner, 1996; Weaver

1 Het begrip 'victim precipitation' is omstreden geraakt vanwege connotaties met het toekennen van 'schuld' aan slachtoffers. We gebruiken de term echter in meer neutrale en verklarende zin. In het Nederlands wordt de term ook wel vertaald als 'provocatie in ruime zin' (Van Dijk, 1997), hetgeen we niet overnemen. Feitelijk gezien geeft de term 'victim precipitation' aan of het slachtoffer bepaalde specifieke gedragingen als eerste initieerde. Het is echter onduidelijk waarom sommige slachtoffers dergelijke gedragingen als eerste vertonen en of we dit als provocerend kunnen kwalificeren.

2 Wel bestaat veel discussie over het relatieve belang van het type wapen of de intentie van de dader bij een fatale uitkomst (o.a. Wells \& Horney, 2002). 
Soenita Ganpat, Joanne van der Leun \& Paul Nieuwbeerta

e.a., 2004), maar ook voor slachtoffers (Felson \& Steadman, 1983; Phillips e.a., 2007).

Samenvattend suggereert de literatuur dat hoe agressiever het slachtoffer is, des te agressiever de dader zal zijn. Tot slot vond het schaarse onderzoek op dit punt dat de manier waarop omstanders zich gedragen tijdens conflicten, variërend van inactiviteit tot bemiddeling of partijdigheid, ook van invloed kan zijn op de uitkomst van incidenten. Hoewel de uitkomst van dit bemiddelend gedrag onduidelijk is (o.a. Felson \& Steadman, 1983; Phillips \& Cooney, 2005), lijkt partijdigheid sterk van invloed te zijn op de kans dat conflicten zullen escaleren (Phillips \& Cooney, 2005).

\section{Het verklaren van fatale uitkomsten}

De literatuur verklaart op verschillende wijzen waarom bepaalde ernstige geweldsincidenten fataal eindigen en andere niet. Vooral de theoretische raamwerken van RAT (Cohen \& Felson, 1979) en Situated Transaction Theory (Luckenbill, 1977) zijn daarbij van belang. RAT verschaft inzichten betreffende de invloed van incidentkenmerken op uitkomsten van geweld. De microvariant van RAT richt zich op drie elementen, namelijk (1) de aanwezigheid van een gemotiveerde dader, (2) de aanwezigheid van een geschikt doelwit/slachtoffer, en (3) inadequaat toezicht. $^{3}$ Dagelijkse routines en activiteiten brengen daders en slachtoffers samen (Felson, 1993; Weaver e.a., 2004). Het vorenstaande maakt duidelijk dat het belangrijk is om zowel daders als slachtoffers als omstanders te bestuderen. Hoewel critici aangeven dat RAT onvoldoende aandacht besteedt aan de interactie tussen daders en slachtoffers gedurende het incident bij het verklaren van criminaliteit (Meier e.a., 2001), beargumenteert Felson (1993) dat RAT ook toegepast kan worden bij het verklaren van geweldsincidenten en dat de interactie tijdens het delict daarbij een rol speelt. Geïnspireerd door het sociaal interactionisme geeft hij aan dat door elke vorm van agressief gedrag als doelgericht te beschouwen, bijvoorbeeld als reactie op gepercipieerd onrecht, RAT ook toegepast kan worden op geweldsdelicten.

Luckenbills Situated Transaction Theory is van belang voor deze studie vanwege de veronderstelling dat een fataal incident het resultaat is van een interactieproces tussen dader, slachtoffer en - indien aanwezig - omstanders. In navolging van Goffman (1967) benadrukt Luckenbill dat geweld vaak wordt gebruikt als middel om gezichtsverlies te voorkomen, reputatie te beschermen of om karakter of moed te tonen. Luckenbill onderscheidt opeenvolgende fasen waarin fatale incidenten zich ontwikkelen, beginnend met een 'opening move' en eindigend in fataal geweld. Dat laatste ziet hij als het product van op zijn minst de dader en het slachtoffer, zij het dat van tevoren niet altijd even duidelijk is wie in welke 'rol' eindigt. Luckenbill heeft geen vergelijking gemaakt met niet-fatale incidenten, en zijn theoretisch kader is bekritiseerd vanwege het verwaarlozen van de rol van de

3 Toezicht of 'guardianship' is een breed begrip, waarvan over de operationalisering weinig consensus bestaat (Reynald, 2009). 
locatie en het tijdstip van incidenten (Weaver e.a., 2004). Om beter te begrijpen waarom bepaalde incidenten fataal eindigen en andere niet, combineren wij daarom Luckenbills werk met RAT.

Wij komen daarmee tot de volgende assumpties: ernstig geweld vindt plaats wanneer een gemotiveerde dader, een geschikt doelwit en afwezigheid van adequate toezichthouders samenkomen in tijd en locatie, zoals RAT veronderstelt. In navolging van Luckenbill voegen we hieraan toe dat gedragingen en reacties van personen ten tijde van het incident ook cruciaal kunnen zijn. We verwachten ten eerste dat het concept van gemotiveerde dader relevant is en veronderstellen - zoals Felson (1993) beargumenteerde - dat de motivatie van daders niet altijd vooraf vaststaat, maar gevormd wordt door de interactie tussen de uiteindelijke dader en het uiteindelijke slachtoffer gedurende het incident. Dit suggereert een bepaalde mate van gepercipieerd onrecht (ibid.) tijdens het incident, waarop daders wellicht overgaan tot (fataal) geweld. We verwachten dat wanneer sprake is van 'victim precipitation'(Wolfgang, 1958), daders wellicht eerder leed zullen toebrengen (in casu hun slachtoffers dodelijk letsel toebrengen), omdat daders mogelijkerwijs eerder geneigd zullen zijn om met wraak te reageren op het gedrag van slachtoffers. We gaan er hiermee van uit dat het gedrag van het slachtoffer ten tijde van het incident ook van belang is bij het bestuderen van ernstige geweldsincidenten. Wij veronderstellen dat hoe agressiever het slachtoffer is ten tijde van het incident, des te agressiever de dader zal zijn (Felson \& Steadman, 1983). Alcohol kan hierbij een rol spelen omdat daders dan gevoeliger zijn voor gepercipieerde belediging of zich minder inhouden.

Ten tweede kunnen sommige slachtoffers aangemerkt worden als geschikt doelwit, omdat zij wellicht door hun gedragingen tot op zekere hoogte aan hun eigen dood bijdragen, bijvoorbeeld wanneer zij onder invloed zijn van alcohol, een wapen tonen of de dader anderszins provoceren. Slachtoffers onder invloed van alcohol zijn wellicht eerder geneigd om iets te zeggen of te doen wat de dader kan provoceren, en zijn minder goed in staat om zichzelf te verdedigen bij een aanval (Wolfgang, 1958). Wanneer slachtoffers een wapen tonen tijdens het incident kunnen daders wellicht - als reactie op gepercipieerd onrecht of gepercipieerde belediging - eerder hun slachtoffers doden.

Zoals Felson (1993) reeds aangaf, kunnen omstanders tot slot aangemerkt worden als toezichthouders, die door hun aanwezigheid en/of gedrag mogelijkerwijs fataal geweld kunnen voorkomen. Op grond van RAT verwachten wij dat dagelijkse routines en leefstijlen ${ }^{4}$ daders en slachtoffers samenbrengen. Indirecte leefstijlindicatoren ${ }^{5}$ die in dezen vaak worden genoemd, zijn demografische kenmerken zoals leeftijd, sekse en etnische achtergrond (Hindelang e.a., 1978). Zo kunnen bepaalde personen (bijv. sommige mannen of bepaalde etnische groepen) - als gevolg van hun dagelijkse activiteiten en leefstijl - wellicht eerder in bepaalde risicovolle situaties terechtkomen, waar - in interactie met anderen geweld sneller kan escaleren tot dodelijke afloop, vooral wanneer sprake is van

4 Een risicovolle leefstijl hangt samen met slachtofferschap en daderschap (o.a. Wittebrood, 2006).

5 Het gebruik van indirecte leefstijlindicatoren wordt echter ook bekritiseerd (Wittebrood, 2006). 
gepercipieerd onrecht of gepercipieerde belediging. Door deze kenmerken als indirecte leefstijlindicatoren te beschouwen incorporeren we door middel van controlevariabelen de verwachting dat deze achtergrondkenmerken er ook toe doen, evenals de relatie tussen dader en slachtoffer, het type geweld en de historie tussen dader en slachtoffer, omdat deze meer in het algemeen belangrijk worden geacht bij het begrijpen van de uitkomst van gewelddadige gebeurtenissen (o.a. Weaver e.a., 2004; Wolfgang, 1958).

\section{Hypothesen}

Gebaseerd op voornoemd theoretisch raamwerk en eerder onderzoek is onze verwachting dat incidentkenmerken, gedragingen van actoren en achtergrondkenmerken van slachtoffers en daders bijdragen aan de afloop van conflictsituaties. Dit leidt tot de volgende hypothesen. Wat betreft incidentkenmerken stelt hypothese 1 dat wanneer incidenten in een woning of in de ochtend plaatsvinden de kans op een fatale afloop toeneemt. Hypothese 2 houdt in dat alcoholgebruik door slachtoffers de kans op een fatale afloop verhoogt; hypothese 3 dat alcoholgebruik door daders de kans op een fatale afloop verhoogt; en hypothese 4 dat de aanwezigheid van omstanders de kans op een fatale afloop verlaagt. Hypothese 5 stelt: hoe groter het aantal aanwezige omstanders, des te lager de kans op een fatale afloop.

Met betrekking tot gedragingen van actoren veronderstelt hypothese 6 dat 'victim precipitation' de kans op een fatale afloop verhoogt; hypothese 7 stelt dat indien slachtoffers een wapen tonen of gebruiken, de kans op een fatale afloop toeneemt; en hypothese 8 dat indien daders een vuurwapen tonen of gebruiken, de kans op een fatale afloop toeneemt. Hypothese 9 a veronderstelt dat bemiddeling door omstanders de kans op een fatale uitkomst verlaagt. Hypothese $9 \mathrm{~b}$ gaat ervan uit dat inactiviteit of partijdigheid van omstanders de kans op een fatale uitkomst vergroot. Demografische kenmerken, slachtoffer-daderrelatie en type geweld fungeren als controlevariabelen.

\section{Data en methode}

Deze studie is gebaseerd op strafzaken die aan de volgende vijf inclusiecriteria voldoen:

1. De zaken zijn ingeschreven in twee van de grootste arrondissementen: Den Haag of Rotterdam. Hiervoor is vooral gekozen omdat Den Haag en Rotterdam twee van de belangrijkste steden zijn waar de overgrote meerderheid van moord-/doodslagzaken plaatsvindt (Ganpat \& Liem, 2012; Nieuwbeerta \& Leistra, 2007).

2. De dader is veroordeeld voor moord/doodslag, of een poging daartoe. De keuze voor veroordeelden is vooral gemaakt om zeker ervan te zijn dat de dader schuldig is bevonden aan het plegen van het misdrijf en omdat veroordeelde zaken over het algemeen vollediger zijn dan zaken in behandeling.

3. Het incident betreft één dader en één slachtoffer. 
4. Beiden waren minimaal 12 jaar ten tijde van het incident. Zaken betreffende artikel 290 (kinderdoodslag) en 291 (kindermoord) Wetboek van Strafrecht (Sr) zijn derhalve uitgesloten.

5. Het dossier was aanwezig op het arrondissementsparket ten tijde van de dataverzameling.

Selecte steekproef van fatale en niet-fatale incidenten

Wij gebruikten twee selecte steekproeven van ernstige gewelddadige incidenten: (1) een selecte steekproef van fatale incidenten bestaande uit moord- of doodslagzaken (periode 2000-2009), ${ }^{6}$ en (2) een geselecteerde steekproef van niet-fatale incidenten bestaande uit 'poging moord/doodslag' (periode 2005-2009). Doodslag betreft het opzettelijk doden van een persoon; moord verwijst naar misdrijven waarbij een persoon opzettelijk en met voorbedachten rade is gedood. Poging moord/doodslag omvat artikel $45 \mathrm{Sr}$ in combinatie met een van de volgende artikelen: artikel 287-291. Ondanks het juridisch onderscheid tussen moord en doodslag is een dergelijk onderscheid niet gemaakt in dit onderzoek, omdat wij de uitkomst van geweldsdelicten (fataal of niet) centraal wilden stellen. Om die reden is gekozen voor een meer sociologische benadering. Bovendien is, anders dan vaak aangenomen, het juridisch onderscheid tussen moord en doodslag niet altijd even helder vast te stellen.

De definitieve selecte steekproef omvat data over 267 incidenten, waarvan 126 met een fatale afloop en 141 met een niet-fatale afloop. Voor de selectie van de eerste groep gebruikten we gegevens afkomstig uit de Monitor Moord en Doodslag (voor meer informatie, zie Ganpat \& Liem, 2012; Nieuwbeerta \& Leistra, 2007). Voor de tweede groep gebruikten wij OM-data van het Openbaar Ministerie over vervolgde strafzaken.

Uit de Monitor Moord en Doodslag selecteerden we alle fatale zaken gepleegd in Den Haag en Rotterdam die ook verder voldeden aan de eerste vier inclusiecriteria $(n=608)$. Van de 608 opgevraagde dossiers zijn 126 zaken opgenomen in deze studie. Van tevoren is een quotum bepaald. Gestreefd werd om ongeveer 100 fatale zaken en 100 niet-fatale zaken in detail te bestuderen. Dit vanwege het tijdrovende karakter van de studie en om toch statistische analyses te kunnen uitvoeren. ${ }^{7}$

Voor de zaken van niet-fataal geweld selecteerden wij willekeurig een totaal van 478 personen uit alle 1.197 personen die in Den Haag of Rotterdam waren vervolgd voor niet-fataal geweld (periode 2005-2009), waarna de bijbehorende strafdossiers zijn opgevraagd. Na het toepassen van de inclusiecriteria zijn 141 nietfatale zaken opgenomen. ${ }^{8}$

6 Aangezien in de praktijk te weinig fatale zaken voorhanden bleken te zijn die aan alle vijf inclusiecriteria voldeden, is de periode voor fatale zaken uiteindelijk uitgebreid.

7 De voornaamste reden voor uitval was afwezigheid van de dossiers, bijvoorbeeld vanwege hoger beroep.

8 De voornaamste reden voor uitval betrof betrokkenheid van meerdere daders of een veroordeling voor een minder ernstig feit. 


\section{Strafdossiers}

Voor dit onderzoek zijn strafdossiers bijzonder waardevol, omdat slachtoffers die gedood zijn niet meer in staat zijn hun verhaal te vertellen. Gedetailleerde informatie over incidentkenmerken en gedragingen van actoren is bovendien vaak afwezig in andere bronnen. Strafdossiers bevatten een schat aan relevante informatie, zoals toxicologische rapporten, ooggetuigenverslagen, resultaten van buurtonderzoek, processen-verbaal, autopsie-/lijkschouwersrapporten, sporenonderzoek, het rapport inzake onderzoek ter terechtzitting, de verklaringen van de dader - en in geval van levende slachtoffers - de verklaringen van slachtoffers. Door een scala aan documenten gedetailleerd te raadplegen konden we ons op aanzienlijk meer baseren dan louter op de daderverklaring (vgl. Luckenbill, 1977). Bij tegenstrijdige informatie volgden wij een hiërarchische afweging gebaseerd op de betrouwbaarheid van de documenten: we deden vooral een beroep op meer objectieve bronnen met een deskundigenoordeel, zoals het onderzoek ter terechtzitting, het sporenonderzoek, het toxicologisch rapport en het psychologisch rapport. De daderverklaring werd beschouwd als de meest subjectieve bron.

Alle gegevens werden systematisch verzameld (in de periode februari-juni 2011) met behulp van het Scoring Instrument (attempted) Homicide (SIH) (Ganpat, 2012), dat zich richt op de rol van specifieke situationele factoren en interacties tussen daders, slachtoffers en omstanders tijdens ernstige geweldsincidenten. Het gaat daarbij om aspecten zoals middelengebruik van dader/slachtoffer, wapenbezit/-gebruik van dader/slachtoffer ten tijde van het incident, context van het incident, aanwezigheid en gedrag van omstanders, chronologische volgorde van gebeurtenissen en achtergrondkenmerken van en relatie tussen dader en slachtoffer. De variabelen zijn gekozen op grond van de theoretische en empirische literatuur over ernstig geweld. Aangezien het huidige artikel primair ingaat op de rol van specifieke situationele kenmerken, is hier ingezoomd op de daarvoor relevante variabelen. De bestudering en codering werden uitgevoerd door acht getrainde onderzoeksassistenten. De score omtrent de interbeoordelaarsbetrouwbaarheid bedroeg .78, hetgeen duidt op een substantiële overeenkomst.

\section{Beschrijving van de totale geselecteerde steekproef}

Van beide selecte steekproeven tezamen waren de meeste slachtoffers en daders man (respectievelijk 70 en 91 procent), gemiddeld in de 30 (respectievelijk $\mathrm{M}=34,6, \mathrm{SD}=14,64$, Range $12-91$ en $\mathrm{M}=31,2, \mathrm{SD}=11,91$, Range 12-75) en in tegenstelling tot de slachtoffers waren de meeste daders niet in Nederland geboren (respectievelijk 52 en 45 procent). Van 35 slachtoffers was het geboorteland onbekend. Wij vonden demografische verschillen in sekse en leeftijd: vrouwelijke slachtoffers (respectievelijk 41 en 20 procent), mannelijke daders (respectievelijk 95 en 88 procent), gemiddeld oudere slachtoffers (respectievelijk 37,5 en 32,2) en oudere daders (respectievelijk 34,8 en 28,0 ) waren vaker betrokken bij fatale dan niet-fatale incidenten (bij 30 slachtoffers en twee daders was de leeftijd onbekend). Andere verschillen in achtergrondkenmerken betroffen het type slachtoffer-daderrelatie, het type geweld en de historie tussen dader en slachtoffer (tabel 1): bij fatale incidenten kenden slachtoffers en daders elkaar vaker (respectievelijk 90 en 77 procent) en hadden zij vaker een intieme relatie met elkaar (res- 
Tabel 1: $\quad$ Achtergrondkenmerken in fatale versus niet-fatale incidenten $(N=267)$

\begin{tabular}{|c|c|c|c|}
\hline & $\begin{array}{l}\text { Fatale incidenten } \\
(\mathrm{N}=\mid 26) \\
\text { (percentages) }\end{array}$ & $\begin{array}{l}\text { Niet-fatale } \\
\text { incidenten } \\
(\mathrm{N}=\mid 4 \mathrm{I}) \\
\text { (percentages) }\end{array}$ & $\mathbf{p}$ \\
\hline \multicolumn{4}{|l|}{ Relatie tussen dader-slachtoffer ${ }^{a}$} \\
\hline (Ex-)partner/familielid & 48 & 26 & ** \\
\hline Vriend/kennis & 42 & 51 & ns \\
\hline Vreemde & 11 & 23 & ** \\
\hline \multicolumn{4}{|l|}{ Type van geweldb } \\
\hline Geweld in de huiselijke/familiesfeer & 54 & 34 & ** \\
\hline $\begin{array}{l}\text { Geweld bij ruzies tussen vrienden, kennissen of } \\
\text { vreemden }\end{array}$ & 36 & 54 & ** \\
\hline Geweld in het criminele milieu en overig geweld & 11 & 12 & ns \\
\hline Historie tussen dader-slachtoffer ${ }^{c}$ & 75 & 60 & * \\
\hline
\end{tabular}

$* \mathrm{p}<.05 ; * * \mathrm{p}<.01, \mathrm{~ns}=$ niet significant

${ }^{a}$ missing $\mathrm{n}=2$.

$b_{\text {missing } n=4 \text {. }}$

cmissing $n=67$.

pectievelijk 38 en 17 procent). Hoewel ongeveer 90 procent van de fatale en nietfatale geweldsincidenten zich in de huiselijke of familiesfeer afspeelde of geweld bij ruzies betrof tussen vrienden, kennissen of onbekenden, bleken fatale incidenten vaker in de huiselijke/familiesfeer te spelen (respectievelijk 54 en 34 procent). Bij fatale incidenten ging het minder vaak om geweld bij ruzies tussen vrienden, kennissen of onbekenden dan bij niet-fatale incidenten (respectievelijk 36 en 54 procent). Verder hadden slachtoffers van fatale incidenten vaker een eerder conflict met de dader dan slachtoffers van niet-fatale incidenten (tabel 1).

\section{Metingen}

Afhankelijke variabele

De afhankelijke dichotome variabele geeft aan of het conflict een fatale afloop (1) dan wel een niet-fatale afloop had (0).

Onafhankelijke variabelen: incidentkenmerken

Incidentkenmerken werden gemeten met zes onafhankelijke variabelen: (1) incidentlocatie (referentiecategorie: woning), (2) tijd van het incident (referentiecategorie: ochtend), (3) alcoholgebruik ${ }^{9}$ door slachtoffer, ongeacht de geconsumeerde hoeveelheid (informatie over de hoeveelheid alcohol ontbrak vaak in de strafdossiers), (4) alcoholgebruik door dader, ongeacht de geconsumeerde hoeveelheid, (5) aanwezigheid van omstanders en (6) aantal aanwezige omstanders (continue vari-

9 Alcoholgebruik kan ook worden aangemerkt als een leefstijlindicator (Wittebrood, 2006). 
abele). Onder omstanders verstaan we: personen die aanwezig waren en getuige waren van het incident, met uitzondering van de dader en het slachtoffer (vgl. Phillips \& Cooney, 2005, 334).

\section{Onafhankelijke variabelen: gedragskenmerken}

Vier (dichotome) onafhankelijke variabelen meten indirect gedragskenmerken: (1) 'victim precipitation' (d.w.z. het uiteindelijke slachtoffer was de eerste die tijdens het incident een vuurwapen of een scherp instrument toonde, of de eerste die fysiek geweld gebruikte (Wolfgang, 1958)), (2) het tonen of gebruiken van een wapen door het slachtoffer - met uitzondering van handen en voeten (definitie gebaseerd op de studie van Felson en Steadman (1983)), (3) het tonen of gebruiken van een vuurwapen door de dader (definitie gebaseerd op de studie van Felson en Steadman (1983)), en (4) gedrag van omstanders (bestaande uit drie dichotome variabelen: partijdigheid (in casu minstens één omstander was partijdig), bemiddeling (in casu minstens één omstander deed een poging om te bemiddelen, maar geen van allen was partijdig) en inactiviteit (in casu geen enkele omstander greep in); referentiecategorie: de afwezigheid van omstanders).

\section{Controlevariabelen en overige variabelen}

Tot slot dienen demografische variabelen - leeftijd (continu), sekse en geboorteland ( 1 =geboren in Nederland; $0=$ =lders) - als controlevariabelen. Overige achtergrondkenmerken omvatten daarnaast slachtoffer-daderrelatie (1=niet-vreemden; $0=$ vreemden), type geweld en historie tussen dader en slachtoffer. Door type geweld op te nemen is rekening gehouden met het feit dat er verschillende geweldsincidenten zijn. Gebaseerd op Nieuwbeerta en Leistra (2007) analyseren wij drie hoofdcategorieën van geweld met dummyvariabelen: (a) geweld in de huiselijke/ familiesfeer, (b) geweld bij ruzies tussen vrienden, kennissen of onbekenden (de referentiecategorie), of (c) geweld in het criminele milieu en overige geweld. Onder historie tussen dader en slachtoffer verstaan we of het slachtoffer eerder een aanvaring of conflict had met de dader. Vanwege het grote aantal missings is deze variabele niet opgenomen in de logistische regressie.

De variabele het dragen van een wapen door de dader dient als beschrijvende variabele voor incidentkenmerken. Voor gedragskenmerken betrof dit de volgende vijf variabelen: (1) belediging door slachtoffer/dader, (2) bedreiging door slachtoffer/dader (om fysiek geweld te gebruiken/om te doden/om een mes of een vuurwapen te tonen), (3) fysiek geweld door slachtoffer/dader, (4) modus operandi, wat refereert naar de wijze waarop de dader de meest ernstige verwonding heeft toegebracht, en (5) eerste gedragingen door het slachtoffer, gemeten door diverse variabelen.

\section{Resultaten}

Beschrijvende analyses zijn als eerste uitgevoerd om onderzoeksvraag $1 \mathrm{a}$ te beantwoorden: in hoeverre zijn er verschillen tussen fatale versus niet-fatale incidenten ten aanzien van incidentkenmerken? Uit tabel 2 blijkt dat het bij fatale incidenten vaker voorkwam dat: (1) incidenten niet op straat of op een parkeer- 
terrein plaatsvonden, (2) daders een vuurwapen droegen, (3) omstanders afwezig waren, en (4) een kleiner aantal omstanders aanwezig was dan bij niet-fatale incidenten.

Tabel 2: $\quad$ Incidentkenmerken in fatale versus niet-fatale incidenten $(N=267)$

\begin{tabular}{|c|c|c|c|}
\hline & $\begin{array}{l}\text { Fatale incidenten } \\
(\mathrm{N}=126) \\
\text { (percentages) }\end{array}$ & $\begin{array}{l}\text { Niet-fatale incidenten } \\
(\mathrm{N}=|4| \text { I) } \\
\text { (percentages) }\end{array}$ & $\mathbf{p}$ \\
\hline \multicolumn{4}{|l|}{ Locatie van het incident ${ }^{\mathrm{a}}$} \\
\hline Woning & 56 & 44 & ns \\
\hline Straat of parkeerplaats & 25 & 41 & $* *$ \\
\hline Café, bar, restaurant & 7 & 6 & ns \\
\hline Overig & 12 & 9 & ns \\
\hline \multicolumn{4}{|l|}{ Tijdstip van het incident ${ }^{b}$} \\
\hline Ochtend (06:00-12:00u) & 18 & 16 & ns \\
\hline Middag (12:00-18:00u) & 22 & 17 & ns \\
\hline Avond (I8:00-24:00u) & 39 & 43 & ns \\
\hline Nacht (00:00-06:00u) & 21 & 24 & ns \\
\hline Alcoholgebruik door slachtoffer & 26 & 20 & ns \\
\hline Alcoholgebruik door dader & 30 & 35 & ns \\
\hline Dader droeg een vuurwapen & 25 & 6 & $* *$ \\
\hline Dader droeg een mes & 24 & 43 & ** \\
\hline Aanwezigheid van omstanders & 56 & 82 & ** \\
\hline Gemiddeld aantal aanwezige omstanders ${ }^{c}$ & $2,40(S D=5,56)$ & $2,43(\mathrm{SD}=3,4 \mathrm{I})$ & $* *$ \\
\hline Range & $0-30$ & $0-25$ & \\
\hline
\end{tabular}

$* \mathrm{p}<.05 ; * * \mathrm{p}<.01, \mathrm{~ns}=$ niet significant

a missing $=\mathrm{I}$.

b missing $=16$.

c Mann-Whitney, missing=4I.

Vervolgens zijn beschrijvende analyses uitgevoerd om de vraag naar verschillen ten aanzien van gedragingen van slachtoffers, daders en omstanders te beantwoorden (onderzoeksvraag 1b). Tabel 3 laat zien dat slachtoffers die gedood zijn vaker de dader beledigden en bedreigden dan slachtoffers die het incident overleefden. Daders van fatale incidenten beledigden daarentegen minder vaak en gebruikten minder vaak fysiek geweld dan daders van niet-fataal geweld. Daders van fatale incidenten toonden of gebruikten niet alleen vaker een vuurwapen, maar zij brachten ook vaker de meest ernstige verwonding toe met een vuurwapen dan daders van niet-fatale incidenten. Bij fataal geweld was vaker sprake van 'victim precipitation' dan bij niet-fataal geweld (tabel 3). Bovendien kwam het bij fatale incidenten vaker voor dat (1) het conflict begonnen was door het slachtoffer, eventueel samen met de dader, (2) slachtoffers de dader als eerste beledigden dan wel bedreigden, en (3) slachtoffers als eerste de ander bedreigden met een vuurwapen of een scherp voorwerp dan slachtoffers van niet-fatale incidenten. 
Tabel 3: Gedragingen van actoren in fatale versus niet-fatale incidenten $(N=267)$

\begin{tabular}{|c|c|c|c|}
\hline & $\begin{array}{l}\text { Fatale incidenten } \\
(\mathrm{N}=\mid 26) \\
\text { (percentages) }\end{array}$ & $\begin{array}{l}\text { Niet-fatale } \\
\text { incidenten } \\
(\mathrm{N}=\mid 4 \mathrm{I}) \\
\text { (percentages) }\end{array}$ & $\mathbf{p}$ \\
\hline \multicolumn{4}{|l|}{ Gedrag van slachtoffer } \\
\hline Slachtoffer beledigde de dader & 32 & 18 & * \\
\hline Slachtoffer bedreigde de dader & 28 & 13 & $* *$ \\
\hline Slachtoffer gebruikte fysiek geweld & 44 & 56 & ns \\
\hline Slachtoffer toonde of gebruikte een wapen & 19 & 13 & ns \\
\hline \multicolumn{4}{|l|}{ Gedrag van dader } \\
\hline Dader beledigde het slachtoffer & 10 & 21 & $*$ \\
\hline Dader bedreigde het slachtoffer & 52 & 62 & ns \\
\hline Dader gebruikte fysiek geweld & 53 & 71 & $* *$ \\
\hline Dader toonde of gebruikte een vuurwapen & 28 & 9 & $* *$ \\
\hline \multicolumn{4}{|l|}{ Daders modus operandi } \\
\hline Verwurging & 14 & 6 & ns \\
\hline Vuurwapen & 27 & 6 & $* *$ \\
\hline Scherp instrument & 54 & 64 & ns \\
\hline $\begin{array}{l}\text { Slaan, schoppen, stoten al dan niet met behulp van } \\
\text { een voorwerp }\end{array}$ & 5 & 18 & $* *$ \\
\hline Overig & I & 5 & - \\
\hline \multicolumn{4}{|l|}{$\begin{array}{l}\text { Eerste gedraging geïnitieerd door het slachtof- } \\
\text { fer }\end{array}$} \\
\hline Victim precipitation & 34 & 23 & * \\
\hline $\begin{array}{l}\text { Conflict gestart door slachtoffer, of door slachtof- } \\
\text { fer en dader gezamenlijk }\end{array}$ & 50 & 38 & $*$ \\
\hline Slachtoffer was de eerste die beledigde & 26 & 14 & * \\
\hline Slachtoffer was de eerste die dreigde & 19 & 8 & ** \\
\hline $\begin{array}{l}\text { Slachtoffer was de eerste die dreigde met een } \\
\text { vuurwapen of mes }\end{array}$ & 14 & 5 & ** \\
\hline $\begin{array}{l}\text { Slachtoffer was de eerste die fysiek geweld } \\
\text { gebruikte }\end{array}$ & 25 & 18 & ns \\
\hline Gedrag van aanwezige omstanders & $\mathrm{N}=64(\%)$ & $\mathrm{N}=113(\%)$ & \\
\hline Partijdigheid & 33 & 45 & ns \\
\hline Bemiddeling & 19 & 24 & ns \\
\hline Inactiviteit & 48 & 31 & $*$ \\
\hline
\end{tabular}

$* \mathrm{p}<.05 ; * * \mathrm{p}<.01, \mathrm{~ns}=$ niet significant

Tot slot kwam het bij fatale incidenten vaker voor dat geen van de omstanders ingreep dan bij niet-fatale incidenten. 
Deze resultaten maken duidelijk dat fatale en niet-fatale incidenten van elkaar verschillen, zowel wat betreft incidentkenmerken als wat betreft gedragingen van actoren.

\section{Multivariate analyses}

Logistische regressies zijn uitgevoerd om onderzoeksvraag $2 \mathrm{a}$ en $2 \mathrm{~b}$ te beantwoorden: in hoeverre zijn incidentkenmerken en gedragingen van slachtoffers, daders en omstanders van invloed op de kans dat geweldsincidenten fataal eindigen? In tabel 4 worden vier modellen gepresenteerd. ${ }^{10}$ In alle modellen zijn onze controlevariabelen opgenomen. Stapsgewijs zijn incidentvariabelen of variabelen betreffende gedragskenmerken toegevoegd (model II en III), en in model IV tegelijkertijd.

Alle modellen laten zien dat mannelijke daders een grotere kans hadden dan vrouwelijke daders om betrokken te raken bij de fatale incidenten. ${ }^{11}$ Hoewel model II een negatieve relatie laat zien tussen het geboorteland van slachtoffers en de uitkomst van incidenten blijkt deze relatie te verdwijnen in de andere modellen. Rekening houdend met het type geweld laat model IV zien dat de kans op een fatale afloop toenam wanneer er sprake was van geweld in de huiselijke/ familiesfeer in vergelijking met geweld bij ruzies tussen vrienden, kennissen of onbekenden.

\section{Incidentkenmerken}

Wanneer we onze hypothesen over effecten van incidentkenmerken toetsen, blijkt - in tegenstelling tot de verwachting in hypothese 1 - dat wanneer incidenten in een woning of in de ochtend plaatsvonden, de kans op een fatale uitkomst niet hoger of lager was. In lijn met hypothese 2 blijkt dat de kansverhouding op een fatale versus niet-fatale afloop vier keer zo groot was wanneer slachtoffers onder invloed waren van alcohol als wanneer zij niet onder invloed waren van alcohol (model IV). In tegenstelling tot de verwachting in hypothese 3 had alcoholgebruik door daders geen invloed op de kans op een fatale afloop. In overeenstemming met hypothese 4 blijkt dat wanneer omstanders aanwezig waren de kans op een fatale afloop afnam. In tegenstelling tot de verwachting in hypothese 5 blijkt daarnaast dat hoe meer omstanders aanwezig waren, des te groter de kans was op een fatale afloop.

\section{Gedragingen van actoren}

In lijn met hypothese 6 - dat 'victim precipitation' een significante positieve invloed zou hebben op de kans op een fatale afloop (model III en IV) - bleek dat de kansverhouding op een fatale versus niet-fatale afloop vier keer zo groot was wanneer er sprake was van 'victim precipitation' (model IV). In tegenstelling tot de verwachting in hypothese 7 had het tonen of gebruiken van een wapen door

10 De VIF-waarde suggereerde geen multicollineariteitsprobleem. Op basis van de Cook's Distancewaarde (afkappunt $\mathrm{Di}<1.0$ ) zijn twee observaties geëxcludeerd.

11 Hoewel geslacht doorgaans het grootste effect heeft, kan dit mogelijkerwijs samenhangen met andere, ongemeten factoren. 
slachtoffers geen significante invloed op de afloop van het incident. In lijn met hypothese 8 blijkt echter dat wanneer daders een vuurwapen toonden of gebruikten de kansverhouding op een fatale versus niet-fatale afloop tien keer zo groot was als wanneer daders geen vuurwapen toonden of gebruikten (model IV). Conform hypothese 9 a blijkt dat wanneer aanwezige omstanders bemiddelden, de kans op een fatale afloop afnam vergeleken met incidenten zonder omstanders (model III en IV). Ten slotte blijkt, in tegenstelling tot de verwachting in hypothese $9 \mathrm{~b}$, dat bij inactieve of partijdige omstanders de kans op een fatale uitkomst afnam in vergelijking met incidenten zonder omstanders (model III en IV).

Samenvattend nam de kans op een fatale afloop toe wanneer sprake was van: (1) alcoholgebruik door het slachtoffer, (2) afwezigheid van omstanders, (3) een groter aantal aanwezige omstanders, (4) het tonen of gebruiken van een vuurwapen door daders, en (5) 'victim precipitation'. 


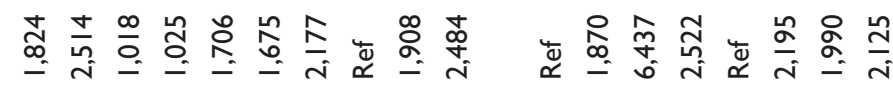

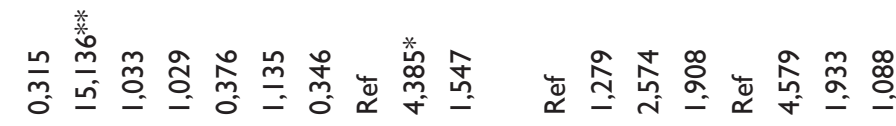

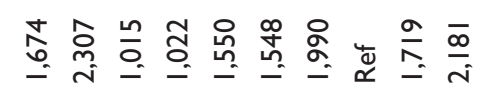

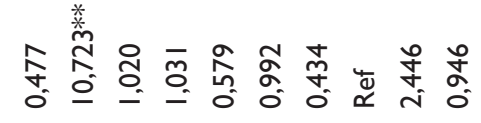

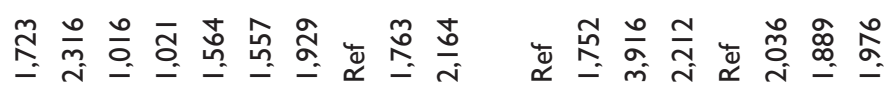

苾蒡

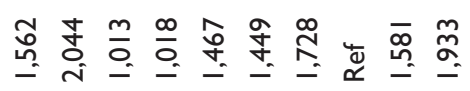

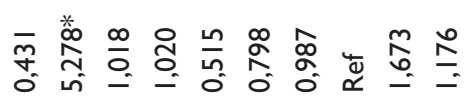

苍

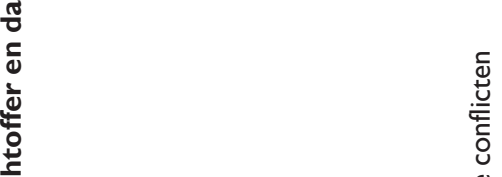

के

s.

ป

$\stackrel{\frac{.0}{20}}{\frac{10}{\infty}}$
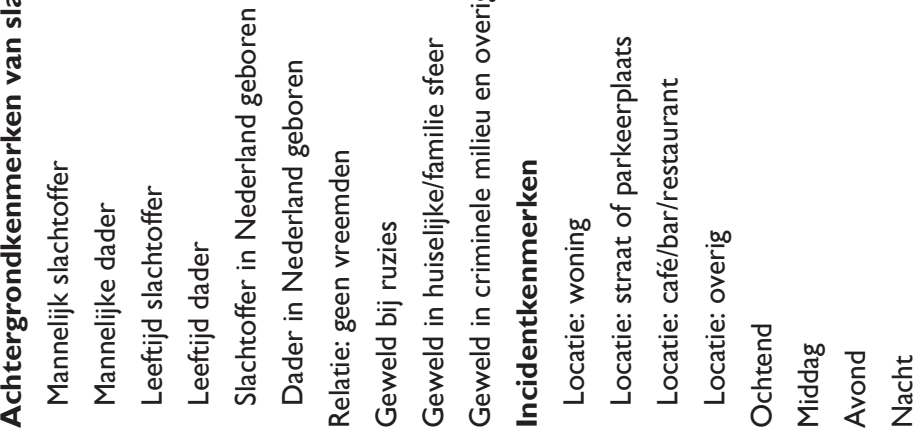


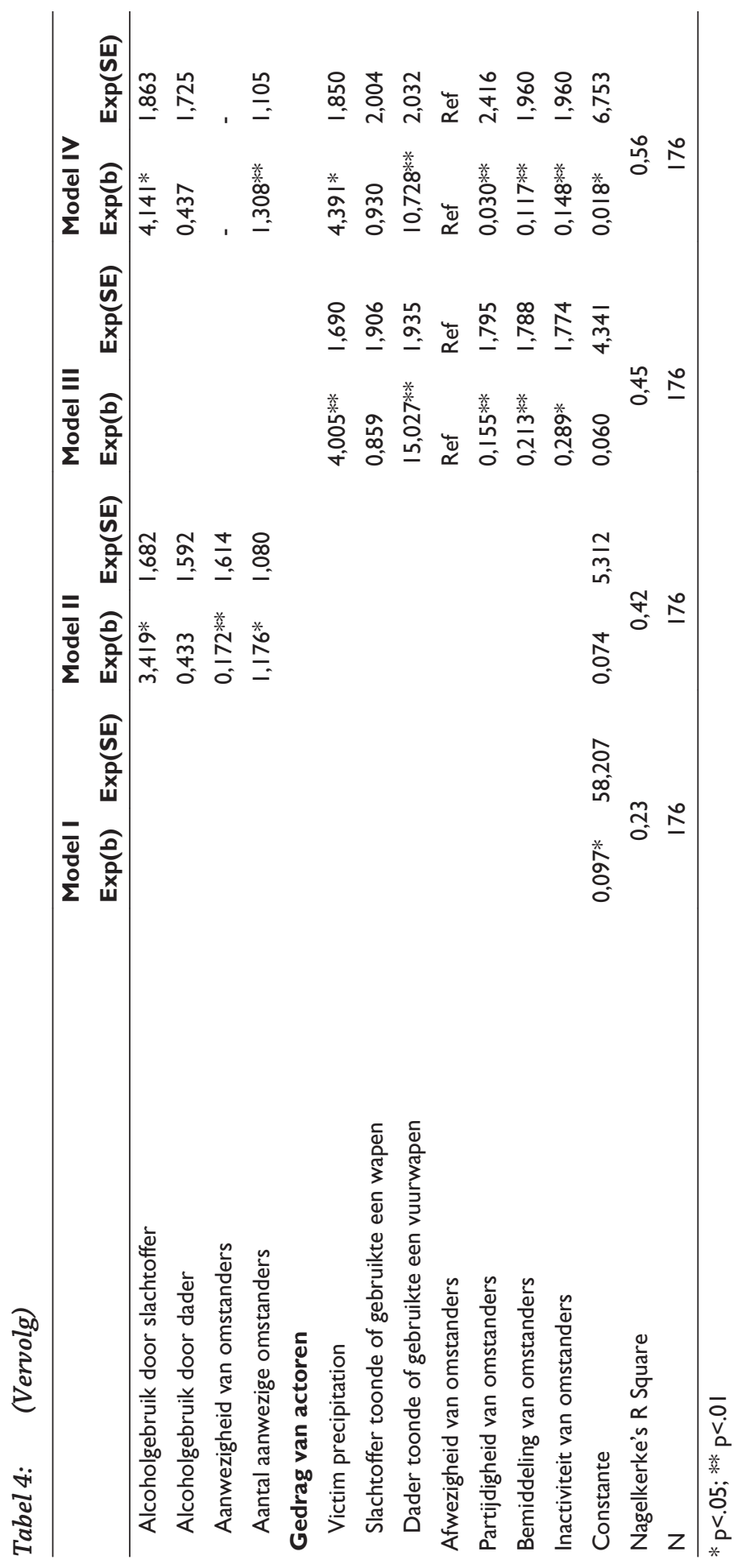




\section{Conclusie en discussie}

Op basis van een vergelijking van uitgebreide strafdossiers komen substantiële verschillen naar voren tussen ernstige geweldsincidenten met een fatale versus niet-fatale afloop wat betreft incidentkenmerken en vooral wat betreft gedragingen van actoren gedurende het incident. Terwijl veel eerdere studies naar situationele kenmerken geen directe vergelijking maakten tussen fatale versus nietfatale geweldsincidenten, louter beschrijvend en incompleet waren vanwege de exclusieve blik op daders, heeft dit onderzoek aan het licht gebracht dat de kans op een fatale afloop significant toenam wanneer sprake was van alcoholgebruik door slachtoffers, het tonen of gebruiken van een vuurwapen door daders, 'victim precipitation' en afwezigheid van omstanders.

De resultaten onderschrijven het belang van een meer dynamische bestudering van de escalatie van ernstige geweldsincidenten: in lijn met eerder onderzoek vonden wij dat - zelfs bij deze specifieke selectie van geweld (namelijk ernstig geweld) - niet alleen het gedrag van de uiteindelijke daders ertoe doet, maar ook de uiteindelijke slachtoffers en omstanders invloed hebben op de afloop van gewelddadige gebeurtenissen. Waar Luckenbill al liet zien dat deze conclusie voor fataal geweld opgaat, hebben wij laten zien dat deze conclusie ook opgaat indien fatale versus niet-fatale geweldsincidenten direct met elkaar worden vergeleken. Bovendien hebben we gedemonstreerd hoe noties van RAT (Cohen \& Felson, 1979) toegepast kunnen worden in het verklaren van ernstig geweld door een vierde noodzakelijk aspect op te nemen in de verklaring. Wij deden dit door expliciet de verbinding te leggen met Luckenbills Situated Transaction Theory. Niet alleen doen motivatie en gelegenheid ertoe - zoals verondersteld door RAT maar ook de manier waarop personen zich gedragen in specifieke omstandigheden (Sacco \& Kennedy, 2011). Tot slot blijkt Wolfgangs 'victim precipitation'-concept (1958) nog altijd relevant te zijn. Het zou mogelijkerwijs dader- en slachtoffertheorieën kunnen integreren in situationeel onderzoek (vgl. Miethe, 1985). Door fatale versus niet-fatale geweldsincidenten expliciet met elkaar te vergelijken heeft dit onderzoek al met al een aantal cruciale factoren aan het licht gebracht die bijdragen aan de escalatie van ernstige geweldsincidenten, die aanzet bieden voor toekomstig onderzoek en verdere theorievorming. Een belangrijke implicatie is dat niet alleen gekeken moet worden naar de rol van de uiteindelijke daders, maar ook naar die van de uiteindelijke slachtoffers en eventuele omstanders.

Dit onderzoek kent ook beperkingen. Ten eerste kunnen we slechts terugkijken op basis van wat de dossiers bieden. Hierdoor was het bijvoorbeeld niet mogelijk ook rekening te houden met de geconsumeerde hoeveelheid alcohol, terwijl de literatuur laat zien dat dosering ook een belangrijke rol kan spelen bij de escalatie van conflicten (o.a. Phillips e.a., 2007). Idealiter zouden de gegevens gecombineerd moeten worden met bijvoorbeeld gegevens uit interviews met daders (Phillips \& Maume, 2007). Een tweede kanttekening betreft onze selectiecriteria. Door te kiezen voor een-op-eenzaken kunnen geen uitspraken worden gedaan over zaken waarbij sprake is van meerdere daders en/of slachtoffers. Verder geldt als kanttekening dat hoewel gepoogd is rekening te houden met diverse typen van 
geweld, het vanwege het relatief kleine aantal zaken niet mogelijk was om gedetailleerder in te zoomen op bepaalde typen van geweld. Een andere kanttekening betreft de focus op situationele factoren, terwijl andere factoren, zoals geneigdheid (Ganpat e.a., 2012; Gottfredson \& Hirschi, 1990), ook relevant kunnen zijn voor een fatale versus niet-fatale afloop van geweldsincidenten. Tot slot zou aanvullend onderzoek naar de opeenvolging van acties tijdens ernstige geweldsincidenten het beeld van incidenten completer en meer dynamisch kunnen maken.

\section{Literatuur}

Apel, R., Dugan, L. \& Powers, R. (2011). Gender and injury risk in incidents of assaultive violence. Justice Quarterly, 1-33.

Beke, B.M.W.A., Haan, W.J.M. de \& Terlouw, G.J. (2001). Geweld verteld. Verklaringen van daders, slachtoffers en getuigen van geweld op straat. Den Haag: WODC.

Cohen, L.E. \& Felson, M. (1979). Social change and crime rate trends: a routine activity approach. American Sociological Review, 44(4), 588-608.

Curtis, L.A. (1974). Victim precipitation and violent crime. Social Problems, 21(4), 594-605.

Darke, S. (2010). The toxicology of homicide offenders and victims: a review. Drug and Alcohol Review, 29(2), 202-215.

Decker, S.H. (1995). Reconstructing homicide events: the role of witnesses in fatal encounters. Journal of Criminal Justice, 23(5), 439-450.

DiCataldo, F. \& Everett, M. (2008). Distinguishing juvenile homicide from violent juvenile offending. International Journal of Offender Therapy and Comparative Criminology, 52(2), 158-174.

Dijk, J.J.M. van (1997). Het victimologische perspectief in verleden, heden en toekomst. Tijdschrift voor Criminologie, 39(4), 292-309.

Dobash, R.E., Dobash, R., Cavanagh, K. \& Medina-Ariza, J. (2007). Lethal and nonlethal violence against an intimate female partner: comparing male murderers to nonlethal abusers. Violence Against Women, 13(4), 329-353.

Dümig, A.G. \& Dijk, J.J.M. van (1975). Acties en reacties van geweldslachtoffers: enige uitkomsten van een victimologisch onderzoek. Tijdschrift voor Criminologie, 17(2), 63-73.

Felson, R.B. (1993). Predatory and dispute-related violence: a social interactionist approach. In R.V. Clarke \& M. Felson (eds.). Routine activity and rational choice, advances in criminological theory. New Brunswick, NJ: Transaction Publishers, 103-126.

Felson, R.B. \& Messner, S.F. (1996). To kill or not to kill? Lethal outcomes in injurious attacks. Criminology, 34(4), 519-545.

Felson, R.B. \& Steadman, H. (1983). Situational factors in disputes leading to criminal violence. Criminology, 21(1), 59-74.

Ganpat, S.M. (2012). Scoring Instrument for (attempted) Homicide. Leiden: Universiteit Leiden.

Ganpat, S.M. \& Liem, M. (2012). Homicide in the Netherlands. In: M.C.A. Liem \& W.A. Pridemore (eds.). Handbook of European homicide research: patterns, explanations, and country studies. New York: Springer, 329-342.

Ganpat, S.M., Liem, M., Leun, J. van der \& Nieuwbeerta, P. (2012). The influence of criminal history on the likelihood of committing lethal vs. nonlethal violence. Homicide Studies. Epub ahead of print 8 November 2012. doi: 10.1177/1088767912466082.

Goffman, E. (1967). Interaction ritual: essays on face-to-face behavior. Garden City, NY: Doubleday. 
Gottfredson, M.R. \& Hirschi, T. (1990). A general theory of crime. Stanford, CA: Stanford University Press.

Hentig, H. von (1948). The criminal and his victim: studies in the sociobiology of crime. New Haven, CT: Yale University Press.

Hindelang, M., Gottfredson, M.R. \& Garofalo, J. (1978). Victims of personal crime: an empirical foundation for a theory of personal victimization. Cambridge, MA: Ballinger.

Latane, B. \& Darley, J.M. (1968). Group inhibition of bystander intervention in emergencies. Journal of Personality and Social Psychology, 10(3), 215-221.

Luckenbill, D. (1977). Criminal homicide as a situated transaction. Social Problems, 25(2), 176-186.

Meier, R.F., Kennedy, L.W. \& Sacco,V.F. (2001). Crime and the criminal event perspective. In: R.F. Meier, L.W. Kennedy \& V.F. Sacco (eds.). The process and structure of crime: criminal events and crime analysis. New Brunswick, NJ: Transaction, 1-27.

Miethe, T.D. (1985). The myth or reality of victim involvement in crime: a review and comment on victim-precipitation research. Sociological Focus, 18(3), 209-220.

Nieuwbeerta, P. \& Leistra, G. (2007). Dodelijk geweld. Moord en doodslag in Nederland. Amsterdam: Balans.

Nieuwenhuis, A. \& Ferwerda, H. (2010). Tot de dood ons scheidt: een onderzoek naar de omvang en kenmerken van moord en doodslag in huiselijke kring. Arnhem: Bureau Beke.

Phillips, S. \& Cooney, M. (2005). Aiding peace, abetting violence: third parties and the management of conflict. American Sociological Review, 70(2), 334-354.

Phillips, S. \& Maume, M. (2007). Have gun will shoot? Weapon instrumentality, intent, and the violent escalation of conflict. Homicide Studies, 11(4), 272-294.

Phillips, S., Matusko, J. \& Tomasovic, E. (2007). Reconsidering the relationship between alcohol and lethal violence. Journal of Interpersonal Violence, 22(1), 66-84.

Planty, M. (2002). Third-party involvement in violent crime, 1993-99. Bureau of Justice Statistics, GPO. Washington, DC.

Reynald, D. (2009). Guardianship in action: a theoretical and empirical elaboration of the routine activity concept. Amsterdam: NSCR.

Sacco, V.F. \& Kennedy, L.W. (2011). The criminal event: an introduction to criminology in Canada. Toronto: Nelson Education Ltd.

Weaver, G., Wittekind, J., Huff-Corzine, L., Corzine, J., Petee, T. \& Jarvis, J. (2004). Violent encounters: a criminal event analysis of lethal and nonlethal outcomes. Journal of Contemporary Criminal Justice, 20, 348-368.

Wells, W. \& Horney, J. (2002). Weapon effects and the individual intent to do harm: influences on the escalation of violence. Criminology, 40, 265-296.

Wittebrood, K. (2006). Slachtoffers van criminaliteit: feiten en achtergronden. Den Haag: Sociaal en Cultureel Planbureau.

Wolfgang, M.E. (1958). Patterns in criminal homicide. Philadelphia: University of Pennsylvania Press. 